\title{
BioLink
}

Jurnal Biologi Lingkungan, Industri, Kesehatan

Available online http://ojs.uma.ac.id/index.php/biolink

\section{THE EFFECT OF KESAMBI BARK EXTRACT ON MICE LYMPHOCYTE COUNT AND SPLEEN INDEX}

\section{Christine Stefani Cleorata Tamelan, Kukuh Madyaningrana*, \& Vinsa Cantya Prakasita}

Biology Study Program, Faculty of Biotechnology, Universitas Kristen Duta Wacana, Yogyakarta, Indonesia

Submited : 09-07-2021; Reviewed : 27-08-2021; Accepted : 04-01-2022

*Corresponding author: E-mail : madvaningrana@staff.ukdw.ac.id

\begin{abstract}
Kesambi is a plant widely used by people of Timor Island. Flavonoid content of Kesambi is potential to be used as immunomodulators. This study aimed to study the effect of Kesambi bark extract on lymphocyte count and spleen index of male mice as an indicator of their immune responses. Research included identification of phytochemical compounds macerated from Kesambi bark, lymphocytes count and spleen index calculation. Mice injected with sheep erythrocytes were treated orally with three doses of Kesambi extract $(0.113 \mathrm{mg} / \mathrm{g} \mathrm{BW}, 0.491 \mathrm{mg} / \mathrm{g} \mathrm{BW}$, and $0.712 \mathrm{mg} / \mathrm{g} \mathrm{BW})$ for 10 days. Lymphocyte count using blood smear method was carried out on day 0, 5 and 10, while lymphocyte count using hematology analyzer and spleen index measurement were performed after mice sacrificed. Kesambi bark contains alkaloids, flavonoids, tannins, and steroids. Treatment with Kesambi bark extract reduced mice lymphocyte count. Administration of $0.491 \mathrm{mg} / \mathrm{gr} \mathrm{BW}$ dose reduced the mice lymphocytes count close to the number of lymphocytes in the negative control group. The spleen index of mice had no correlation with changes in the number of lymphocytes. This preliminary study shows a potential use of Kesambi bark extract as a natural immunosuppressant.
\end{abstract}

Keywords: Kesambi; Lymphocytes; Spleen Index; Mice

How to Cite: Tamelan, C.S.C., Madyaningrana, K., \& Prakasita, V.C. (2022). The Effect Of Kesambi Bark Extract On Mice Lymphocyte Count And Spleen Index, BioLink: Jurnal Biologi Lingkungan, Industri dan Kesehatan, Vol. 8 (2): Hal. 195-206 


\section{INTRODUCTION}

Kesambi is a commonly found plant in Timor Island and traditionally used as medicinal plant (Anonymous, 2015).

Several active compounds such as triterpenoids, phenolic, alkaloids, and flavonoids contained in kesambi bark supported its potency to be used as traditional medicines. Kesambi bark also has antibacterial activity against Staphylococcus aureus (Puspita et al., 2019). Holil \& Griana (2020) stated that flavonol as active compound of kesambi bark extract is potential to induce immunomodulation effect. Flavonol, which is a flavonoid compounds, is able to stimulate phagocytic cells to carry out phagocytic responses as an effort to increase the immune response, possessed antioxidant activity that can suppress tumor growth and adjust immune system through the proliferation and activation of T and B lymphocytes (Haeria et al., 2017).

Though it has many benefits, research on Kesambi, especially on its bark, is still limited and rare. Some of the tests carried out were only limited to the crude extract and not yet specific. Based on Kesambi beneficial potency, this research aimed to study the effect of Kesambi (Schleichera oleosa (Lour.) Oken) bark extract on lymphocyte count and spleen index of male mice (Mus musculus $\mathrm{L}$ ) as indicators of their immune responses.

\section{MATERIALS AND METHODS}

\section{Extract Preparation and Yield Calculation}

Four hundred gram of Kesambi bark simplicia powder was placed into macerator, then dissolved in $4 \mathrm{~L}$ of $70 \%$ ethanol, stirred until homogeneous and kept in a light-proof room for $5 \times 24$ hours while stirring occasionally. On day 5 , solution was filtered using filter paper and evaporated using a rotary evaporator to obtain a thick extract (Tenda et al., 2017). The yield of kesambi bark extract was calculated using formula as follows:

$$
\text { Yield }=\frac{\text { extract weight }}{\text { simplicia weight }} \times 100 \%
$$

\section{Qualitative Biochemical Test}

\section{Alkaloid test}

A total of $5 \mathrm{~mL}$ of $2 \mathrm{~N} \mathrm{HCl}$ was added to $0.3 \mathrm{~g}$ of kesambi bark extract in a test tube and heated for 2-3 minutes while stirring. After cooling, $0.3 \mathrm{~g}$ of $\mathrm{NaCl}$ was added to the test tube and filtered. The filtrate was added with $5 \mathrm{~mL}$ of $2 \mathrm{~N} \mathrm{HCl}$ and divided into $1 \mathrm{~A}, 1 \mathrm{~B}$, and $1 \mathrm{C}$ solutions. Solution 1A was used as a blank. Solution 1B was added with Mayer's reagent. Appearance of cloudy solution after Mayer's reagent addition indicated the 
presence of alkaloid compounds. Solution 1C was added with Wagner's reagent and formation of precipitate indicates the presence of alkaloid compounds (Marliana, 2011).

An amount of $0.3 \mathrm{~g}$ of kesambi bark extract was dissolved in $3 \mathrm{~mL}$ of $\mathrm{n}$-hexane, added with ethanol and divided into 3 parts of solutions $2 \mathrm{~A}, 2 \mathrm{~B}$, and $2 \mathrm{C}$. Solution $2 \mathrm{~A}$ was used as a blank. Solution 2B was added with $0.5 \mathrm{~mL}$ of $\mathrm{HCl}$ and heated while the color change was observed. The slowly formation of a bright red or purple color indicates the presence of leukoantocyanin compounds. Solution 2C was added with $0.5 \mathrm{~mL}$ of concentrated $\mathrm{HCl}$ and 4 pieces of magnesium and color change was observed. The $2 \mathrm{C}$ solution would then be diluted using distilled water, added with 1 $\mathrm{mL}$ of butanol, homogenized and observed for color changes. Color change to red orange, pale red, or dark red indicates the presence of flavonoid compounds (Marliana, 2011).

\section{Tannin test}

As much as $0.3 \mathrm{~g}$ of kesambi bark extract was dissolved in $10 \mathrm{~mL}$ of hot distilled water and 3-4 drops of $10 \% \mathrm{NaCl}$ were added. The homogeneous solution was then filtered and divided into 2 parts, namely $3 \mathrm{~A}$ and $3 \mathrm{~B}$. Solution $3 \mathrm{~A}$ was used as a blank, while into solution 3B a little of gelatin solution and $5 \mathrm{~mL}$ of $10 \% \mathrm{NaCl}$ solution were added to observe the changes that occurred. The presence of a white precipitate indicates that it contains tannin compounds (Marliana, 2011).

\section{Steroid test}

Fifteen milliliters of ethanol was added to $0.3 \mathrm{~g}$ of kesambi bark extract and divided into 3 parts of solution $4 \mathrm{~A}, 4 \mathrm{~B}$, and 4C. Solution 4A was used as a blank, solution $4 \mathrm{~B}$ was added with 3 drops of H2SO4 then shaken slowly to produce a green-blue-red-purple-light yellow color indicating a positive result. In the $4 \mathrm{C}$ tube, 1-2 mL of concentrated $\mathrm{H} 2 \mathrm{SO} 4$ was added. If a red ring is formed, it indicates the presence of steroid compounds (Marliana, 2011).

\section{Saponin test}

A total of $0.3 \mathrm{~g}$ of kesambi stem bark extract was dissolved in $5 \mathrm{~mL}$ of distilled water and then vortexed for 30 seconds. Saponin is indicated by the formation of stable foam with a height of $3 \mathrm{~cm}$ above the surface of the liquid for more than 1 minute (Marliana, 2011).

\section{Preparation of Sheep Erithrocytes Suspension}

Sheep blood was divided into 4 falcon tubes and centrifuged at $3000 \mathrm{rpm}$ for 10 minutes. Supernatant was discarded, Phosphate Buffer Saline (PBS) was added 
as much as three times of pellets volume and then centrifuged again. This process was repeated for 3 times in order to obtain pure erythrocytes free from blood plasma proteins. After the last centrifugation, supernatant was discarded and PBS was added as much as the volume of pellets so that $50 \%$ of erythrocytes was obtained. From the existing $50 \%$ of erythrocytes, 0.4 $\mathrm{mL}$ was taken and diluted in $9.6 \mathrm{~mL}$ of PBS to obtain $2 \%$ erythrocytes.

\section{Gas Chromatography-Mass}

\section{Spectroscopy (GC-MS) Analysis}

Quantitative phytochemical assays were carried out at the LPPT of Universitas Gadjah Mada Yogyakarta using Gas Chromatography-Mass Spectroscopy (GCMS) with following equipment conditions: UHP Helium carrier gas ( $\mathrm{He})$, injector temperature 260 oC, split flow 50 $\mathrm{mL} /$ minute, split ratio 50 , front inlet flow $1.00 \mathrm{~mL} /$ minute, MS transfer line temp $250^{\circ} \mathrm{C}$, ion source temp $200^{\circ} \mathrm{C}$, purge flow 3
$\mathrm{mL} /$ minute, gas saver flow $5 \mathrm{~mL} /$ minute, gas saver time 5 minutes.

Acclimatization and Treatment of Test Animals

Male Balb/c mice (Mus musculus L) as test animals were treated according to ethical standards stated by Medical Research Ethics Commission, Faculty of Medicine, Universitas Kristen Duta Wacana in the Statement of Ethical Eligibility number 1331/C.16/FK/2021 which was issued on August 11, 2021.

Before being treated, 25 male Balb/c mice were adapted and fed for seven days. After the acclimatization process, mice were randomly taken and divided into 5 groups. Each group consisted of 5 male mice. Kesambi bark extract doses to be applied to mice were calculated using formula used by Wahyu et al (2021):

$$
\frac{\mathrm{A}(\text { animal })}{\mathrm{B}(\text { human })}=\frac{\mathrm{Km} \mathrm{B}}{\mathrm{Km} \mathrm{A}}
$$

Treatment of each group of test animals is shown in Table 1 as follows:

$\underline{\text { Table 1. Description of treatment and dose to mice }}$

\begin{tabular}{cl}
\hline Group & \multicolumn{1}{c}{ Treatment } \\
\hline Control- $(\mathrm{K}-)$ & Aquadest injection $+0.2 \mathrm{ml}$ of distilled water orally \\
Control $+(\mathrm{K}+)$ & HRD $2 \%$ injection $+0.2 \mathrm{ml}$ of distilled water orally \\
EKBK 12.5 & HRD $2 \%$ injection + extract $0.113 \mathrm{mg} / \mathrm{kg}$ BW orally \\
EKBK 50 & HRD $2 \%$ injection + extract $0.491 \mathrm{mg} / \mathrm{kg} \mathrm{BW}$ orally \\
EKBK 75 & HRD $2 \%$ injection + extract $0.712 \mathrm{mg} / \mathrm{kg} \mathrm{BW}$ orally \\
\hline
\end{tabular}

Each preparation is given once a day for 10 days. 


\section{Lymphocyte Cell Count}

On day 0 , day 5 and day 10, blood smear preparations were made to count the number of mice lymphocytes. The percentage of lymphocytes from a total of 100 leukocyte cells was calculated using formula according to Hartika et al., (2014):

$$
\% \text { Lymphocyte }=\frac{\text { Z Lymphocyte }}{100} \times 100 \%
$$

On the 10th day, mice were anaesthetized using chloroform, dissected and $1 \mathrm{~mL}$ of blood was taken from the heart. Blood samples were inserted into the EDTA vacutainer tube for routine hematological analysis at Sadewa Clinical Laboratory Yogyakarta.

\section{Spleen Index Calculation}

Spleen organ was collected from dissected mice on day 10. Mice weight before sacrifice was also documented. Both data were used on spleen index calculation. Spleen index was calculated using formula described by Fatirah et al., (2019) as follows:

$$
\text { organ index }=\frac{\text { organ weight }(\mathrm{g})}{\text { animal weight }(\mathrm{g})}
$$

\section{RESULTS AND DISCUSSION}

\section{Kesambi Bark Extract}

Simplicia powder of Kesambi bark extracted using maceration method produced $295.38 \mathrm{~g}$ of extract. This ethanolic extract has a paste form, blackish brown color, and aromatic odor. The average yield value of $96 \%$ ethanol kesambi bark extract was $19.69 \%$. This study used a non-stratified maceration method, so it was gained a lower yield when compared to research conducted by Istiqomah et al., (2021) which used stratified maceration method. In their study, Istiqomah et al., (2021) gained $25.86 \%$ of kesambi bark extract yield. Based on Permadi et al., (2015), stratified maceration method produces a higher yield value when compared to non-stratified maceration.

\section{Identification of Phytochemical Groups of Kesambi Bark Extract with Qualitative Biochemical Tests}

As shown in Table 2, we identified the presence of alkaloids, flavonoids, tannins and steroids on Kesambi bark extract. Istiqomah et al., (2021) showed that ethanol extract of kesambi bark contained alkaloids, flavonoids, and tannins. In contrast to mentioned studies, the results of phytochemical tests in Mariyah's research (2020) stated that alkaloid compounds were not identified in the kesambi peel extract. Differences in phytochemical test results can be influenced by environmental conditions where plants grow and the age of the 
sample used (Supriatna et al., 2019).

Table 2. Results of identification of groups of phytochemical compounds

\begin{tabular}{lc}
\hline \multicolumn{1}{l}{ Test } & Results \\
\hline Alkaloids & + \\
Flavonoids & + \\
Tannins & + \\
Steroids & + \\
Saponins & - \\
\hline Note: & \\
+: Detected group of compounds tested, \\
-: No class of compound was detected
\end{tabular}

Gas Chromatography-Mass Spectroscopy (GC-MS) Analysis

Compound analysis using GC-MS succeeded in detecting 13 compounds with 4 main compounds having the highest peaks. First highest peak at retention time 43.33 minutes and area percentage $7.60 \%$ was detected as 7,8-Epoxylanostan-11-ol, 3-acetoxy which is a triterpenoid steroidal derivative compound. This group of compounds has pharmacological activity in the form of anti-inflammatory which can reduce and inhibit the inflammatory process (Iswary et al., 2019). Second highest peak in retention time 43.44 minutes and the area percentage $6.26 \%$ was detected as 2,4,6,8,10Tetradecapentaenoic acid, 9a-(acetyloxy)$1 \mathrm{a}, 1 \mathrm{~b}, 4,4$ a derivative compound of terpenoids (Abdel-Rahman et al.,, 2019). This compound has anti-inflammatory properties which can both inhibit production of TNF- $\alpha$ and expression of cyclooxygenase-2 which can affect the formation of prostaglandins during inflammatory process (Tanjaya, 2015). The third highest peak at retention time of 45.71 minutes and area percentage of $35.50 \%$ was identified as Methyl glycocholate, a derivative of 3 Trimethylsilyl (TMS). The fourth highest peak at retention time of 54.87 minutes and area percentage of $4.81 \%$ was identified as 3-Pyridinecarboxylic acid, 2,7,10-tris(acetyloxy)-1,1a,2,3,4,6,7,1.

\section{Effects of Kesambi Bark Extract on Lymphocyte Count of Male White Mice}

Lymphocytes count using blood smear method (Figure 1) showed the mean value of lymphocytes in the negative control treatment group (-) on day 0 was the lowest one when compared to positive control (+), low dose (0.113 mg/gBW), medium (0.491 mg/gBW), and high doses (0.712 mg/gBW) treatment groups. The administration of sheep erythrocytes as an antigen affected the changes on mice lymphocyte count. Sheep erithrocytes were injected 2 times into mice within period of 7 days. The first dose was injected on H-7 and the second dose was injected on $\mathrm{H}-\mathrm{O}$ of treatment. 


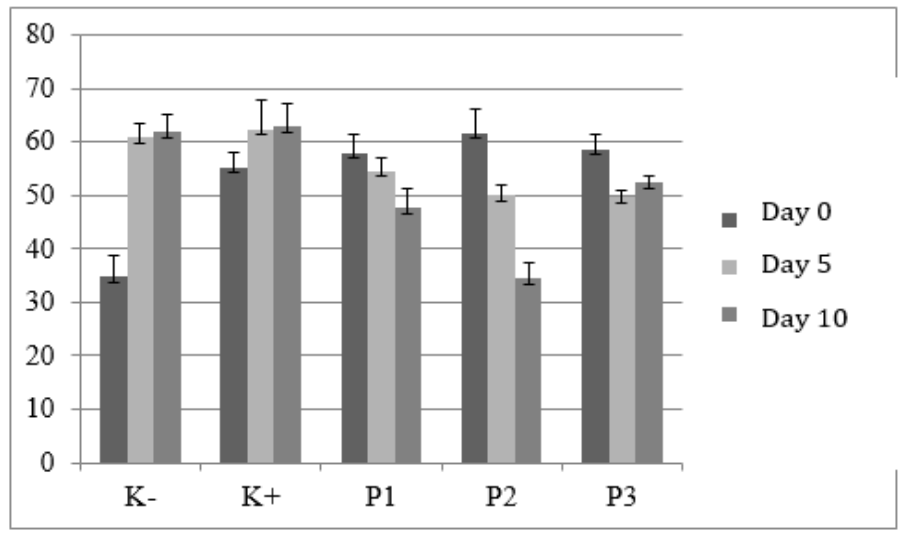

Figure 1. Number of mice lymphocytes on the application of Kesambi bark extract for 10 days as counted with blood smear method

Note:

K-: Negative Control (-), K+: Positive Control (+), P1:Low Dose (0.113 mg/gBW), P2: Medium Dose (0.491 mg/gBW), P3: High Dose (0.712 mg/gBW)

Lymphocytes count from sheep erythrocytes-treated mice on day 0 using blood smear method made 2 hours after injection showed average cell count above 50 cells. On the other hand, negative control (-) treatment group which was only injected with distilled water had the lowest lymphocyte count with an average value of 34.8 cells. This observation supported the idea that sheep erythrocyte as an antigen was able to stimulate mice immune system by increasing the number of lymphocytes. Situngkir study in 2021 obtained the same result. They mentioned an increase of mice immune response when induced with $2 \%$ sheep erythrocytes. Sheep erythrocytes is known to have strong negative charge that will bind to antibodies. Stonger immune response will be induced by more foreign antigen (Novitae, 2013).
As observed on day 5, there was an increase in the number of mice lymphocyte in negative control (-) and positive control (+) treatment groups, while number of lymphocyte in all Kesambi bark extract treatment groups mice were decreased.

Mice lymphocyte count of negative control $(-)$, positive control $(+)$, and low dose $(0.113 \mathrm{mg} / \mathrm{gBW})$ groups on day 10 increased and was inversely proportional to the number of lymphocytes in the medium dose (0.491 mg/gBW) and high dose $(0.712 \mathrm{mg} / \mathrm{gBW})$ treatment groups. High dose of Kesambi bark extract was less able to inhibit antigen effect in mice circulatory and resulted in the accumulation of leukocytes. The results of this study were in accordance with a study conducted by Dani in 2012 which showed a change in the number of leukocytes that was marked by a decrease of lymphocyte 
number in the granulation tissue of male wistar rats.

Based on the study of Puspita et al.,(2019), flavonoids were the most dominant compounds possessed by Kesambi, all in its bark, leaves, fruits and seeds. Flavonoid content of Kesambi organ extract acts as an anti-inflammatory which can block the release of arachidonic acid and the secretion of lysozyme to inhibit the proliferative and exudative phases of cells involved in inflammation (Rinidar et al, 2018). This inhibitory activity results in reduced arachidonic substrate for the cyclooxygenase and lipoxygenase pathways so it can suppress the amount of prostaglandins, prostacyclins, endoperoxides, hydroxatetraenoic acid, and leukotrienes. Reduction of these various compounds can affect inflammation process and leukocyte migration which resulted in the suppression of increasing lymphocytes number (Aria et al, 2020; Attiq et al, 2018).
Inhibition of prostaglandin pathway by flavonoids was able to reduce vasodilation and local blood flow so that migration of leukocytes to the site of inflammation decreases (Hämäläinen et al, 2011).

The mean of lymphocyte as counted using hematology analyzer performed on day 10 (Figure 2) showed a relatively similar pattern to the lymphocyte count using blood smear method. However, calculations using hematology analyzer obtained higher mean number of lymphocytes than blood smear method. Calculation using hematology analyzer produce more accurate result of leucocyte differential calculation and easier to evaluate the data. Calculation using simpler blood smear method has limitations due to the uneven distribution of leukocyte cells on the slide, resulting in differences in the number of counted cells in each preparation (Sugiarto et al, 2011).

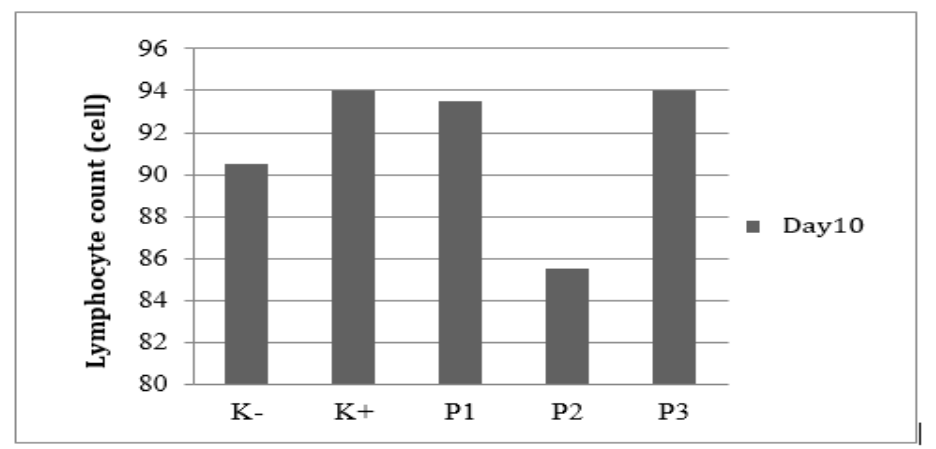

Note:

Figure 2. Number of mice lymphocytes on day 10 counted using hematology analyzer.

K-: Negative Control (-), K+: Positive Control (+), P1:Low Dose (0.113 mg/gBW), P2: Medium Dose (0.491 mg/gBW), P3: High Dose $(0.712 \mathrm{mg} / \mathrm{gBW})$ 
Morphology of mice lymphocytes as nuclei and surrounded by cytoplasm observed on blood smears preparation (Utami et al., 2020).

(Figure 3) showed dark purple cells, round

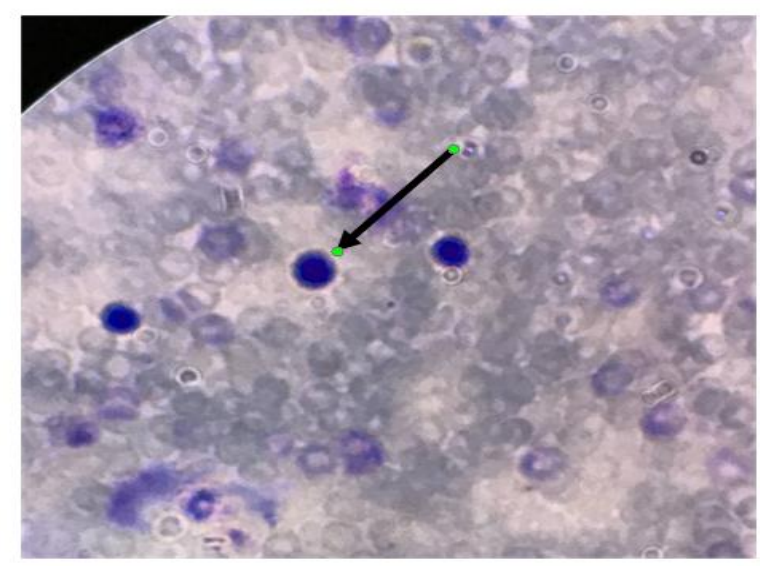

Figure 3. Morphology of mice lymphocytes under microscopy observation (100x magnification) Image source: personal documentation

\section{Spleen Index}

The spleen is an organ that contains white blood cells including lymphocytes which have important roles on body immune response. Nugroho (2018) stated that the increase in the weight of spleen is directly proportional to the increased number of leukocytes, and increasing preserved in a fixative for 1 month.

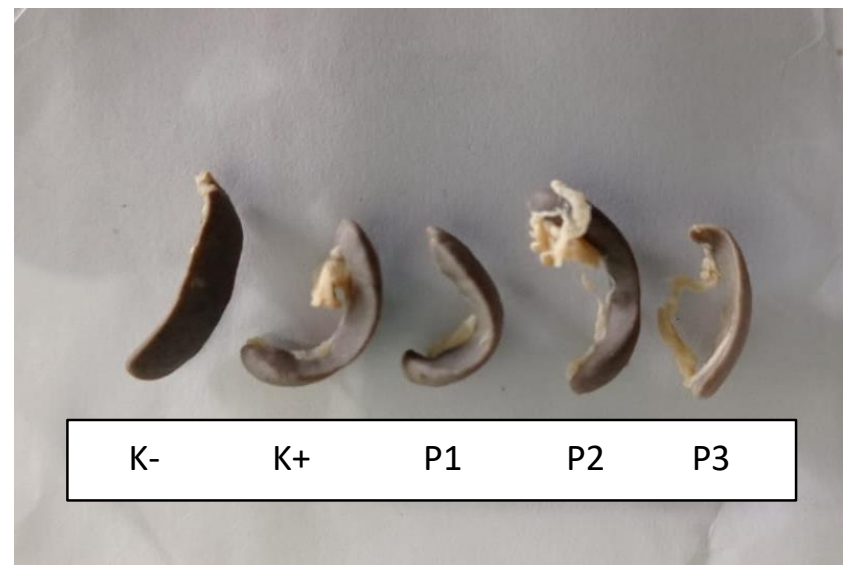

Figure 4. Representative images of mice spleen from various treatments groups Note :

K-: Negative Control (-), K+: Positive Control (+), P1:Low Dose (0.113 mg/g BW), P2: Medium Dose (0.491 mg/gBW), P3: High Dose $(0.712 \mathrm{mg} / \mathrm{gBW})$ 
Mice spleen index that is calculated in the negative control group. Statistical on day 10 showed that mice from high dose analysis of spleen index data of test animals treatment group had the highest spleen in all treatments showed no significant index (Table 3). Mice from medium dose difference in the weight of the mice spleen treatment (P2) showed low spleen index in each treatment group.

which was close to the spleen index of mice

Table 3. Spleen index of mice in 5 treatment groups

\begin{tabular}{ccc}
\hline Treatment & Average Spleen Weight (g) & Spleen Index \\
\hline K- & 0.269 & 125.5 \\
K+ & 0.207 & 162.2 \\
P1 & 0.160 & 164.5 \\
P2 & 0.193 & 136.4 \\
P3 & 0.148 & 202.5 \\
\hline
\end{tabular}

Note :

K-: Negative Control (-), K+: Positive Control (+), P1:Low Dose (0.113 mg/gBW), P2: Medium Dose (0.491 mg/gBW), P3: High Dose $(0.712 \mathrm{mg} / \mathrm{gBW})$

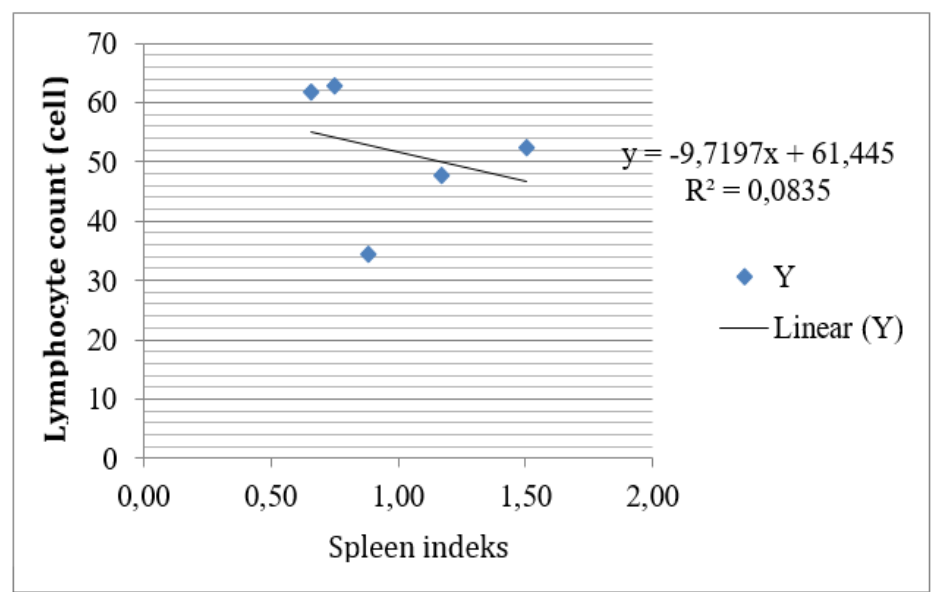

Figure 5. Correlation between mice spleen index and lymphocyte count

Based on the results of simple linear regression analysis in Figure 5 , the coefficient of determination is 0.0835 , which means that the influence of the spleen index on the number of lymphocytes is $8.35 \%$. The significance value obtained is 0.627 ( $\mathrm{P}>0.05)$, so it can be concluded that the spleen index did not have a significant effect on the number of lymphocytes.

\section{CONCLUSION}

Ethanolic extract of kesambi bark (Schleichera oleosa (Lour.) Oken) contained phytochemical groups of alkaloids, flavonoids, tannins and steroids which were detected with qualitative biochemical tests. Kesambi bark extract has the potency to reduce number of lymphocytes in mice-induced sheep erythrocytes. The most effective dose of 204 
Kesambi bark extract to reduce mice lymphocytes was $0.491 \mathrm{mg} / \mathrm{grBW}$, resulted in 48.67 cells as the lowest lymphocyte count. Decreased number of mice lymphocytes observed in this study was not correlated with their spleen index.

\section{ACKNOWLEDGEMENT}

The authors would like to thank to Faculty of Biotechnology, Universitas Kristen Duta Wacana, Yogyakarta for granting internal research funding in 2021. Authors expresses our gratitude to all whom already assisted in conducting this research.

\section{REFERENCES}

Abdel-Rahman, T., Hussein, A. S., Beshir, S., Hamed, A. R., Ali, E., \& El-Tanany, S. S. (2019). Antimicrobial Activity of Terpenoids Extracted from Annona muricata Seeds and its Endophytic Aspergillus niger Strain $\mathrm{SH}_{3}$ Either Singly or in Combination. Macedonian Journal of Medical Sciences, 7(19), 3127-3131.

Anonim. (2015). Prosiding Seminar Nasional Biodiversitas Savana Nusa Tenggara. Kupang. Balai Litbang LHK.

Aria, M., Wardi, E. S., Ayu, S. P. (2020). Uji Efek Anti-inflamasi Ekstrak Etanol Daun Piladang (Plectranthus scutellarioides (L.) R.Br.) yang diberikan secara Topikal terhadap Mencit Putih Betina. Jurnal farmasi Indonesia. Vol.17(1),71-79

Attiq, A., Jalil, J., Husain, K., \& Ahmad, W. (2018). Raging the War Against Inflammation With Natural Products. Front. Pharmacol. 9:976.doi: 10.3389/fphar.2018.00976

Dani F, R. (2012). Potensi Ekstrak Umbi Teki (Cyperus rotundus L.) Dalam Menurunkan Jumlah Limfosit Jaringan Granulasi Setelah Pencabutan Gigi Tikus Wistar Jantan. [skripsi]. Universitas Jember, Jember.
Fatirah, N., Gama, S. I., \& Rusli, R. (2019). Pengujian Toksisitas Produk Herbal Secara In Vivo. Proceeding of Mulawarman Pharmaceuticals Conferences, 9(1), 14-21.

Haeria, Dhuha, \& Hasbi. (2017). Uji efek imonomodulator ekstrak daun kemangi (Ocimum basilicum L.) dengan parameter aktivitas dan kapasitas fagositosis sel makrofag pada mencit (Mus musculus) jantan. Jurnal Farmasi Galenika, 4(1), 1-7.

Hämäläinen, M., Riina Nieminen,R., Zaini Asmawi, M.Z., Vuorela, P., Vapaatalo, H.\& Moilanen,E. (2011). Effects of flavonoids on prostaglandin E2 production and on COX-2 and mPGES-1 expressions in activated macrophages. Planta Med, 77(13),1504-11. doi: $10.1055 /$ s-0030-1270762

Hartika, R., Mustahal, \& Putra, A. N. (2014). Gambaran darah ikan nila (Oreochromis niloticus) dengan penambahan dosis prebiotik yang berbeda dalam pakan. Jurnal Perikanan dan Kelautan, 4 (1), 459-267.

Holil, K. \& Griana, T, P. (2020). Analisis Fitokimia dan Aktivitas Antioksidan Ekstrak Daun Kesambi (Schleichera oleosa) Metode DPPH. Journal of Islamic Pharmacy, 5 (1), 2832.

Istiqomah., Yahdi., \& Dewi Y, K. (2021). Uji Aktivitas Antioksidan Dari Ekstrak Kulit Batang Kesambi [Schleichera oleosa (Lour) Oken] Menggunakan Metode Ekstraksi Bertingkat. SPIN-Jurnal Kimia \& Pendidikan Kimia, 3(1), 22-31.

Iswary, D.A.F., Faisal, \& Risandiansyah, R. (2019). Efek Penambahan Fraksi Polar F24-F28 Ekstrak Metanol Meniran (Phyllanthus niruri) Terhadap Daya Hambat Amoksisilin dan Kloramfenikol Pada Staphylococcus aureus dan Escherichia coli. Jurnal Bio Komplementer Medicine, 6(3).

Mariyah, Y. (2020). Uji fitokimia dan aktivitas antioksidan ekstrak Kesambi (Schleichera oleosa (Lour.) Oken) dengan pelarut metanol. [skripsi]. Universitas Islam Negeri Maulana Malik Ibrahim, Malang.

Marliana, E. \& Saleh, C. (2011). Uji Fitokimia dan Aktivitas Antibakteri Ekstrak Kasar Etanol, Fraksi nHeksana, Etil asetat, dan Metanol dari Buah Labu Air (Lagenari siceraria (Morliana). Jurnal Kimia Mulawarman, 8(2), 39-63.

Novitae, R. (2013). pengaruh pemberian madu kelengkeng (Nephelium longata L) terhadap jumlah sel darah putih pada hewan uji tikus putih jantan galur wistar. [skripsi]. Universitas Sanata Dharma, Yogyakarta. 
Nugroho, R.A. (2018). Mengenal Mencit Sebagai Hewan uji. Mulawarman University Press. Samarinda.

Permadi, A., Sutanto \& Wardatun, S. (2015). Perbandingan Metode Ekstraksi Bertingkat dan Tidak Bertingkat Terhadap Flavonoid Total Herba Ciplukan (Physalis angulata L.) Secara Kolorimetri. Jurnal Online Mahasiswa (JOM) Bidang Farmasi, 1 (1), 1-10.

Puspita, S., Sugita, P. \& Santoso, A. (2019). Aktivitas Antioksidan, Antibakteri, dan Toksisitas Ekstrak Kulit Batang Pohon Kesambi (Schleichera oleosa (Lour) Oken). Jurnal Jamu Indonesia, 4(3), 112-118.

Rinidar, Marzuki, L.A., Safitri, E., Isa, M.,, Hasan, M.,Amiruddin, Lubis, T.M, Hennivanda, Hamzah, A., Asmilia,N.\& Sutriana, A. (2018). The Potency Of Sernai Leaves (Wedelia biflora) to Increase Healing of contusion in Rats (Rattus norvegicus). Proceeding of the 2oth FAVA Congress \& The 15th KIVNAS PDHI, 190-192

Situngkir, O. R. (2021). Efek Imunomodulator Ekstrak Etanol dan Air Daun Kelapa Sawit (Elaeis guineensis Jacq.) Terhadap Total Leukosit dan Titer Antibodi Sel Imun Tikus Jantan. [skripsi]. Universitas Sumatra Utara, Medan.

Sugiarto, C. Lismayanti, L. \& Dalimoenthe, N. Z. (2011). Leukositosis Ber-flagging Bintang (*) Berpotensi Adanya Interferensi Alat Analisis
Hematologi Otomatis. Indonesian Journal of Clinical Pathology and Medical Laboratory, 17 (2), 121-124.

Supriatna, D. Mulyani, Y. Rostini, I. \& Agung, M, U, K. (2019). Aktivitas Antioksidan, Kadar Total Flavonoid Dan Fenol Ekstrak Metanol Kulit Batang Mangrove Berdasarkan Stadia Pertumbuhannya. Jurnal Perikanan dan Kelautan, 10 (2), 35-42.

Tanjaya A. (2015). Uji Aktivitas Antiinflamasi Dan Antipiretik Ekstrak Etanol Biji Petai (Parkia speciosa Hassk) Pada Tikus Putih Jantan Galur Wistar. [skripsi]. Universitas Tanjungpura, Pontianak.

Tenda, P. E., Lenggu, M. Y., \& Ngale, M. S. (2017). Uji Aktivitas Antibakteri Ekstrak Etanol Kulit Pohon Faloak (Sterculia sp.) Terhadap Bakteri Staphylococcus aureus. Jurnal Info Kesehatan, 15(1), 227-239.

Utami, E, T. Risqillah, U. \& Fajariah, S. (2020). Profil Hematologi Mencit (Mus musculus L.) Strain Balb/c Jantan Akibat Paparan Asap Rokok Elektrik. Jurnal Biologi Udayana, 24 (2), 115-125.

Wahyu, H.S. Madyaningrana, K \& Prakasita, V.C. (2021). Effects of Pucuk Merah (Syzygium myrtifolium (Roxb.) Walp.) Leaves Extract on Lymphocytes Count and Spleen Index of Male Balb/C Strain Mice (Mus musculus L.). Scholar Academic Journal of Bioscience. 9(9),248-255 